\title{
衛星画像データによる沖縄リーフ海域における 赤土堆積状況把握の試み
}

\section{1. はじめに}

衛星リモートセンシングを利用した沿岸海洋污染の解 析は従来から盛んに行われているが，その対象として は, 水表面付近に打忷る水質污濁・水温に関するものが ほとんどである、しかしながら，沿岸海洋污染の実態解 明に当たっては，海底底質に関する情報が必要とされる 場合も少なくない。

そこで本研究では, 可視光にはある程度の水中透過性 があるという点に着目し, 水深が $10 \mathrm{~m}$ 程度以下で水が 比較的澄んだ穏やかな沿岸海域では海底底質情報の抽出 が原理的に可能であると洘光, それによる沿岸海洋污染 の評価を新たに試みた。

具体的には，ここでは解析対象として沖縄のリーフ海 域に和ける赤土堆積問題を取り上げ, LANDSAT 衛星 画像データによるリーフ海域での海底に打ける赤土堆積 状況の把握を試みた。

\section{2. 解析対象領域ならびに衛星画像データの 概要}

本論文で示す内容は, 沖縄本島中北部におけるリーフ 海域の衛星画像データを対象とした解析結果である.

衛星データとしては, LANDSATう号の TM センサ 一による画像データを用いている. このセンサーには可 視域から熱赤外域の範囲内に 7 つの波長域 BAND が設 定されており，それらの空間解像度はBAND 1〜5およ び7で約 $30 \mathrm{~m}$, BAND 6 で約 $120 \mathrm{~m}$ である. このう ち, BAND 1 3 は可視光領域にあって, 大体 BAND 1 が青， 2 が緑， 3 が赤色の波長域に対応している. こ れらの可視光はある程度の水中透過性を有し, 特に, 透 過率の高い青・緑色の波長域データでは, 澄んだ海域に おいて約 $12 \mathrm{~m}$ 程度屯での深さの情報を得たという報告 がある（黒田ら，1977）。

沖縄本島の沿岸域には, 図-1に模式的に示すよう に, 沖合数 $100 \mathrm{~m}$ ないし数 $\mathrm{km}$ にまで広がる, ごく浅 い水深のリーフ海域が存在している.このリーフ海域の

\footnotetext{
* 正会員 工博 東京工業大学助教授 工学部土木工学科

** 学生員東京工業大学大学院 土木工学専攻
}

\author{
灘 岡 和 夫*. 田 村 英 寿**
}

水深は, 潮位にもよるが, およそ 1〜3 m 程度であり, 比較的深い場所でも $10 \mathrm{~m}$ 以下である. また，降雨時に この海域に流出した赤土は, その大半が $2 \sim 3$ 日のらち に海底に堆積し, 海水の濁りは法とんど見られなくなる ことが知られている(翁長ら，1990）.ここで対象とした 衛星画像データの撮影日(1986年 7 月15日)には, その 1 週間前から晴れないし量りといった穏やかな天候が 続いていたことから、リーフ海域の水は比較的よく澄ん でいたと考えられる.

このようなことから，今回対象とした可視光領域の衛 星画像データを解析することにより，沖縄リーフ海域に おケる赤土堆積状況に関する海底情報を抽出することが 可能であると考觉られる.

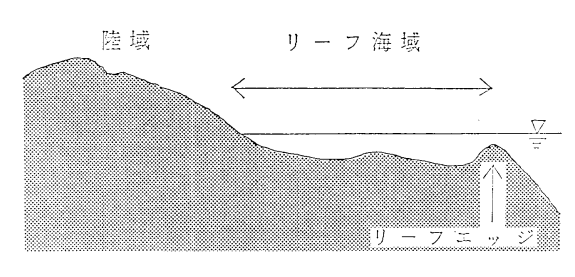

図一1 沖縄本島海岸部の断面図(模式図)

\section{3. 解析手法}

\section{（1）画像データの前処理}

解析対象とする衛星画像には，海域の他に陸域や雲な ぞが混在していることから，それらをまず分離しておく 必要がある.ここでは, 近赤外波長域にある BAND 4 の輝度値が海域でかなり小さくなるという事実を利用し て海域の分離を行った（沢本ら，1985）.

また, 海域のような輝度值の場所的な変化が微小な領 域においては, パスラジアンスなどの大気の影響が無視 し得ないものとなる. そのため, 分離後の海域画像デー タに対して何らかの大気補正を行ら必要があるが，ここ では，大気の影響がない場合に近赤外領域の BAND 4, 5 の輝度值が海域で厓とどゼロになることを利用して この補正を行った。すなわち，この BANDの輝度值が ゼロからずれていれば，その偏差が大気の影響に相当す 
ると考えて, 本来の解析対象としている可視領域の BAND 1 3 の輝度値からその偏差值を差し引くことで 大気の影響を除去ないしは軽減することを試みた。

な扔，BAND4 のデータにはストライピングノイズ の影響が強く見られたため, ここでは BAND 5 の輝度 值を用いて上記の補正を行ったが，各バンドに含まれる 大気の影響が BAND 5 と同じ輝度值で現れるとは限ら ないため, 本来ならば BAND 5 の輝度值適当な重み を掛けて差し引きを行う必要がある。しかしながら，今 回使用したデータに関しては，単純に重みを 1 として演 算処理を行ったところ，BAND 1〜3 の各 BAND とも 良好な結果が得られた。

\section{(2) 画像解析上のポイント}

さきに述べたように，水深がごく浅いリーフ海域を対 象とする場合には，ある程度の水中透過性を有する可視 光領域の衛星画像データを用いることにより, 海底の赤 土堆積状況に関する情報を得ることが原理的に可能なは ずである、しかしながら，このことは同時に，水深の違 いによる光の減哀など水深の変化に直接関連した情報も 輝度データに反映し得ることを意味している.

そこで，ここではまず，これらのことを具体的に把握 して扔くために, 赤土堆積の有無と水深変化の効果が画 像データにどのように現れるかを具体的に見ておくこと にする.

図一2（a)（c）は，沖縄本島の海戝からある程度の リーフ上の水深データが得られる場所の中で, 赤土堆積 が見られる場所 (名護市屋我地島周辺) と見られない場 所（知念村知念岬周辺）の 2 箇所を選定し，それぞれに ついて BAND 1 3 の輝度值を横軸飞水深 $h$ をとって 示したものである.これを見ると，以下のことがわかる

1）赤土堆積がある場所では, ない場所と比べてBAND

1 では輝度值が低く, BAND 2 では同程度, BAND

3 では若干高くなるといら傾向が現れている.

2）各 BAND とも，小さな水深領域で輝度值が明確な 水深依存性を示して招り，逆滛る水深以上になると 輝度值はほぽ一定になる。

3）特に BAND 3 では, 他の 2 つの BAND と比べて より浅い水深から一定の輝度值となっている.

上記の 1) のような形で赤土堆積の有無が輝度データ に反映していることから，これらの画像データから赤土 堆積状況に関する情報を抽出できる可能性があることが わかる. しかしながら, 赤土堆積がない場所に拉いても 水深の違いによって輝度值がかなり変化して打り, この ような生の輝度值のまをでは, 赤土堆積状況そのものを 表す指標とはなり得ないことがわかる.

また，赤土堆積の有無に対する輝度值の差はそれほど 明膫ではない。このことも, このような生の輝度值のま

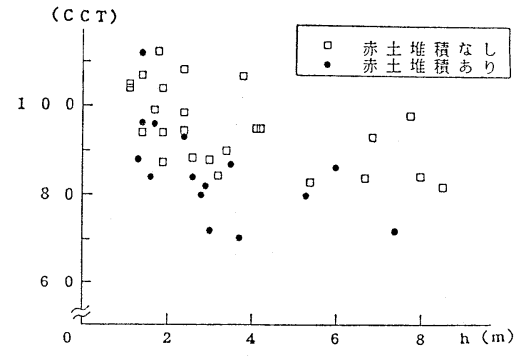

(a) $B \wedge N D \quad 1$

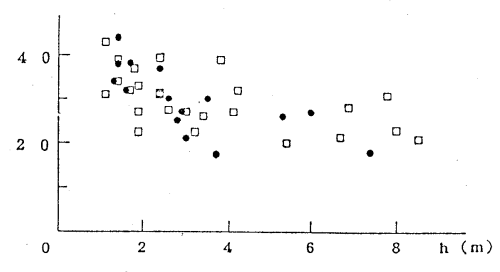

(b) BAND 2

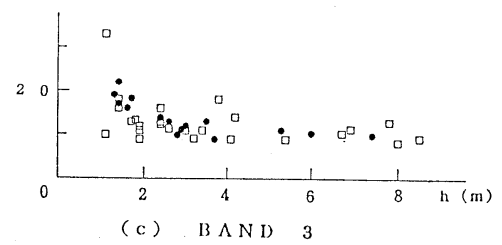

図-2 BAND 1〜3 の輝度値と水深との関係

までは有用な赤土堆積指標となり得ないことを意味して いる.

したがって，i）水深依存性ができるだけ小さく， ii） 赤土堆積の有無や程度をできるだけ鋭敏に反映し得る， 合理的な赤土堆積指標を新たに開発する必要があり，そ の成否が衛星画像から赤土堆積情報を得ることの可能性 を基本的に左右することになる.

な沶，ある程度の水深まで明確な水深依存性が現れる といらことは，その程度までの水深であれば海底情報を 抽出し得ることを意味しているが，3）で述べているよ 万に, BAND 3 ではこの水深がごく浅い. このことは, BAND 3 の波長域の光が, BAND 1 や 2 と比べて水中 透過性が低下することと対応している. したがって, 対 象が赤土だからといらことで, 単純に赤色に近いBAND 3 の輝度データだけを用いることには問題がある.

\section{（3） 赤土堆積指標の開発}

ここでは，3つの方法に基づいて赤土堆積指標を導出 することを試みた。そそのうちの二つは, 衛星画像解析に よく用いられる主成分分析ならびにバンド間の差をとる といら手法に基づくもので, 残る一つは今回新たに開発 した光学的原理に基づく理論的指標である.

以下に, これらの 3 つの手法による指標の内容につい て述べるとともに，具体的な解析結果を示すことによっ て, 今回新たに理論的に導いた堆積指標が最も妥当なる のであることを示す. 
表-1 主成分分析による計算結果

\begin{tabular}{r|c|r|r}
\hline & 第1主成分 & \multicolumn{1}{|c|}{2} & \multicolumn{1}{c}{3} \\
\hline \hline BAND 1 & 0.4965 & -0.6218 & 0.4334 \\
\hline 2 & 0.8529 & -0.0275 & -1.0172 \\
\hline 3 & 0.6584 & 0.8930 & 0.5278 \\
\hline \hline 符与㱍 & $77.7 \%$ & $20.2 \%$ & $2.1 \%$ \\
\hline
\end{tabular}
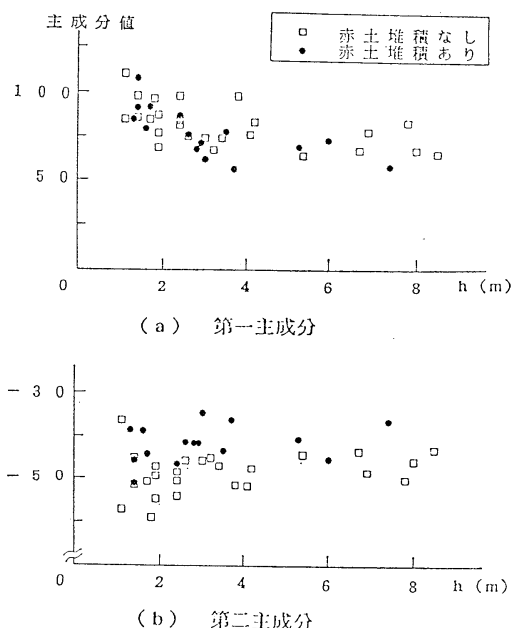

図-3 各主成分と水深との関係

\section{a）主成分分析による方法}

1〜3の各 BAND の輝度值には水深の影響などのよ うな共通因子が含末れることから，これらの各バンドの 輝度値は互いにある程度相関関係をるち，主成分分析に よるデータの集約が可能であると考光られる，そこで実 際に解析対象としているリーフ海域の BAND 1 3 の データに関して主成分分析を行うことによりこれらの 3 バンドのデータを総合化した指標を得ることを試み た.

表一1 飞, 主成分分析の結果を示す。これから，第 1 主成分と第 2 主成分の寄与率が，それぞれ約 78\% 括よ

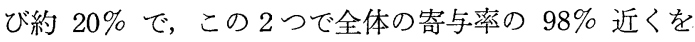
占めていることがわかる，そこで，（2）で述べた 2 箇

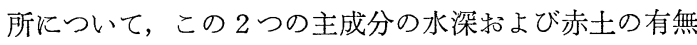
に対する依存性を調べてみた，その結果が，図一3（a)， （b）である. 禾ず第一主成分を見ると，赤土堆積の有無 に注とんど無関係で，から全体的に右下がりの分布形に なっていることから，これが水深情報を主として表す指 標となっていることがわかる。一方，第 2 主成分は，逆 飞水深には活とんぞ依存して扔らず, 赤土堆積の有無に 対応してデータが分離して現れている.したがって，こ の第，2主成分が赤土堆積指標として使える可能性がある が，水深依存性はかなり除去できているものの，赤土堆

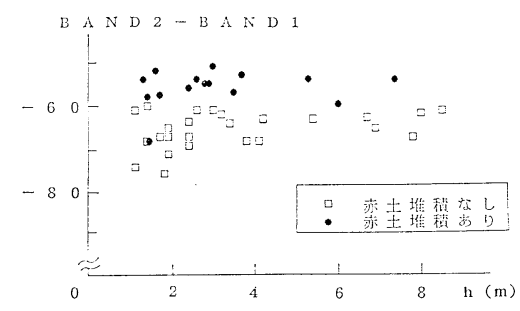

図一4 BAND 1，2 の差による赤土堆積指標と水深との関 係

積の有無に対する指標值の分離具合は十分とはいえな (.

b ）バンド間の差をとる方法

上記のように, 各 BAND の輝度值には水深情報が含 まれているが，これはどの BANDにも現れる共通要因 である。この上うな場合，この共通要因を取り除くため によく用いられる方法として，2つのバンド間で輝度值 の差をとる方法がある，そこでここでは，水中透過率が 比較的高い BAND 1，2 を対象としてその輝度值の差 をとる演算処理を行った，その場合，本来は各輝度値に 対して重みをつけて演算処理を行う必要があるが，ここ では濁りの少ない沿岸海水中でのこの 2 つ波長域にお ける水中消散俰数すなわち水中透過率が添注等しいこと （杉森，1982）を考慮して，重みを1として計算した.

図一4 は, この演算によって得られた値に関して, や はり先ほどと同様に水深及び赤土堆積の有無に対する依 存性を調べた結果を示したものである。これから，この 指標值に水深依存性が注とんど見られず，しかも先の第 2 主成分の指標に比べて赤土堆積の有無に対する値の分 離具合が向上していることがわかる、しかしながら，こ の程度の分離ではまだ赤土堆積指標としては十分ではな く, 実際この指標で画像を作成してみたところ, 特にリ ーフエッジあたりで値が高くなってしをうという不合理 な点が現れてしまった。

c）光学的原理に基づく理論的堆積指標

(バンド間の比をとる方法)

そこで最後に, 光学的原理に基づいた理論的な考察に よりより合理的な指標を導出することを試みた。

海底面に抢ける赤土堆積の有無や程度の違いは, 海底 面での光の反射特性の変化となって現れると考光られ る.そこで，ここではまず各 BAND のセンサーへの入 射光量に関して光の散乱・吸収・反射を考慮した理論式を たて，さらに若干の仮定を導入したらえで理論展開を行 らことにより，海底での反射特性を表す指標を導いた。

まずセンサーへの BAND i の入射光量は, 次式の上 らに表せる（例光ば，杉森，1982）。

$$
\begin{aligned}
E_{z}\left(\Delta \lambda_{i}\right)= & {\left[\Gamma\left(\lambda_{i}\right) \exp \left\{-(\sec \theta+\sec \dot{\phi}) K\left(\lambda_{i}\right) h\right\}\right.} \\
& \left.+\Gamma_{a / w}\left(\lambda_{i}\right)\right] L_{\lambda i} \Delta \lambda_{i}+I_{s c}\left(\Delta \lambda_{i}\right) \cdots \cdots(
\end{aligned}
$$


ここに,

$E_{z}\left(\Delta \lambda_{i}\right):$ センサーへの入射光量, $h:$ 水深

$\Gamma\left(\lambda_{i}\right)$ : 海底面での反射率, $L_{\lambda}$ : 入射光と天空光の和

$\Gamma_{a / w}\left(\lambda_{i}\right)$ : 水面での反射率, $\Delta \lambda$ : 波長帯幅

$K\left(\lambda_{i}\right):$ 水中での消散係数, $\theta, \phi:$ 水面下の入射屈折角

$I_{s c}\left(\Delta \lambda_{i}\right)$ : 水中・大気中の散乱光のうちセンサーヘ入射

するものの和.

ここで，水深が十分に大きい海域に持けるセンサーへの

入射光量 $E_{\infty}\left(\lambda_{i}\right)$ を導入することにより, 式 (1) は次 のよらに表される（以下，深水域および浅水域の海水の 光の透過率は等しいという仮定で議論を進める).

$$
\begin{aligned}
E_{z}\left(\Delta \lambda_{i}\right)= & \Gamma\left(\lambda_{i}\right) \exp \left\{-(\sec \theta+\sec \phi) K\left(\lambda_{i}\right) h\right\} \\
& \cdot L_{\lambda i} \Delta \lambda_{i}+E_{\infty}\left(\Delta \lambda_{i}\right) \quad \ldots \ldots \ldots \ldots \ldots \ldots \ldots \ldots \ldots \ldots \ldots
\end{aligned}
$$

ここでは水中透過率の良いBAND 1 と 2 のみを対象と することとし，それぞれについて式（2）をたて，それ を用いて次のように水深 $h$ の影響を排除する.

$$
\begin{aligned}
\frac{\ln \frac{E_{z}\left(\Delta \lambda_{2}\right)-E_{\infty}\left(\Delta \lambda_{2}\right)}{\Gamma\left(\lambda_{2}\right) L_{22} \Delta \lambda_{2}}}{\ln \frac{E_{z}\left(\Delta \lambda_{1}\right)-E_{\infty}\left(\Delta \lambda_{1}\right)}{\Gamma\left(\lambda_{1}\right) L_{\lambda 1} \Delta \lambda_{1}}} & =\frac{(\sec \theta+\sec \phi) K\left(\lambda_{2}\right) h}{(\sec \theta+\sec \phi) K\left(\lambda_{1}\right) h} \\
& =\frac{K\left(\lambda_{2}\right)}{K\left(\lambda_{1}\right)} \quad \cdots \cdots \cdots \cdots(3)
\end{aligned}
$$

ここで, BAND 1，2 の消散係数がほぼ等しいとみな して（杉森，1982）， $K\left(\lambda_{1}\right)=K\left(\lambda_{2}\right)$ と仮定することに より, 式（3）は次のように表される.

$$
\frac{E_{z}\left(\Delta \lambda_{2}\right)-E_{\infty}\left(\Delta \lambda_{2}\right)}{\Gamma\left(\lambda_{2}\right) L_{\lambda 2} \Delta \lambda_{2}}=\frac{E_{z}\left(\Delta \lambda_{1}\right)-E_{\infty}\left(\Delta \lambda_{1}\right)}{\Gamma\left(\lambda_{1}\right) L_{\lambda 1} \Delta \lambda_{1}} \ldots
$$

さらに, センサーの出力 $V_{i}$ は入射光量 $E_{z}\left(\Delta \lambda_{i}\right)$ に比 例するので，比例定数を $\alpha_{i}$ として

$$
V_{i}=\alpha_{i} E_{z}\left(\Delta \lambda_{i}\right)
$$

とすると，最終的に次式が得られる.

$$
\frac{V_{2}-V_{\infty 2}}{V_{1}-V_{\infty 1}}=C \frac{\Gamma\left(\lambda_{2}\right)}{\Gamma\left(\lambda_{1}\right)}
$$

ここに,

$$
C=\frac{\alpha_{2} L_{\lambda 2} \Delta \lambda_{2}}{\alpha_{1} L_{\lambda 1} \Delta \lambda_{1}}
$$

で，したがって，このCは場所に依存しない定数とみな せる．このことから，式（6）の左辺は海底面の反射特 性を表す指標となっていることがわかる。

さきに述べたように，ここではこの反射特性指標（具 体的には BAND 1 と BAND 2 の海底での反射率の比 に比例する量）が赤土堆積状況を表す指標になると考兄 ている. 図一5（a)，(b) は，このことを具体的に検討 したもので, BAND 1 と 2 の輝度值 $V_{1}$ と $V_{2}$ を横軸 と縦軸にとって表している. 図中の○印は，水深無限大 での輝度值に対応する座標 $\left(V_{\infty 1}, V_{\infty 2}\right)$ を示している.

式（6）の左辺で示される指標は，このグラフ上でち ょらどこの○印を起点とした傾き $\theta$ を表わしているが， この図からわかるよらに, 赤土堆積があるケースではな

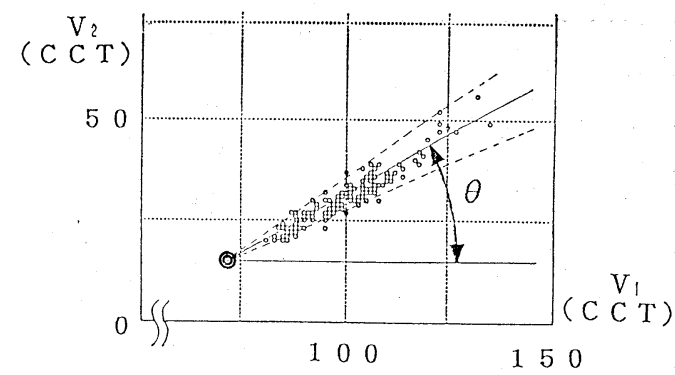

（a）赤土堆積が見られない場所（知念玔付近）

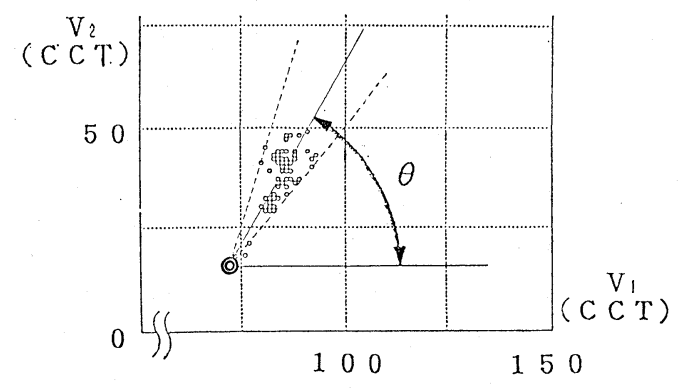

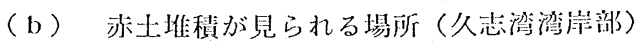

図一5 赤土堆積の有無による BAND 1，2 の輝度特性

いケースに比べて $\theta$ が全体的にかなり大きくなってお り, しかもある程度の分布幅を持っている. したがって 式(6)の左辺の值が赤土堆積指標として十分使える可能 性があることがわかる.

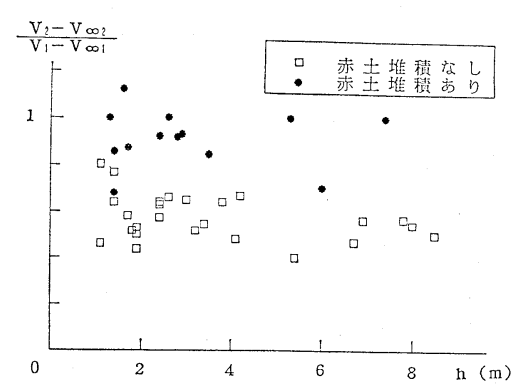

図一6 光学的原理に基づいた理論的赤土琟積指標と水深と の関係

そこで，この指標の定量的な面での特性を a）とb） で示した指標と比べるため，さきと同様に，この指標に ついて水深及び赤土堆積の有無に対する依存性を調べ た. その結果が図一6である，この結果から，この指標 の示す值に水深依存性がほとんど見られず，しかも赤土 堆積の有無に対する值の差が，他の指標のものと比べて かなり大きくなっていることがわかる，したがってこれ らのことから，ここで理論的に導いた指標が，赤土堆積 指標として最も優れたものであることがわかる. 


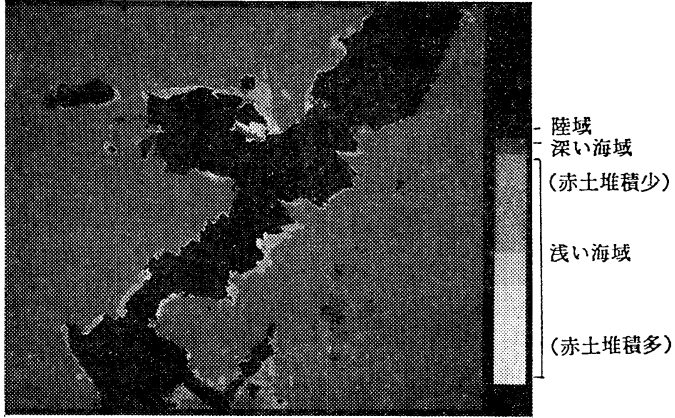

図一7 理論的赤土堆積指標による画像

図一7は，この理論的指標を用いて作成した沖緡本島 リーフ上の赤土堆積状況を示す画像である. 一方, 図一 8 は, 沖縄県公害衛生研究所によって測定されたりーフ 上の底質のサンプリング結果（大見謝・池間，1990）を 示したもので, 図中の記号がサンプリングポイントを表 しており，その中の国印が赤土堆積が顕著にみられた場 所を示している. 図一7をこの図-8 と比較することに より, ここで示した指標値による值が, 実際の赤土堆積 状況とよく合致した結果を示していることがわかる.

\section{4.おわりに}

本研究では, 可視光がある程度の水中透過性を持つこ と飞着目し, 衛星りモセンデータによって沖縄りーフ海 域の海底に括ける赤土堆積状況を把握することを試み た. そして光学的原理に基づいた理論的な考察により, リーフ海域に扔ける衛星画像データの解析法として, 水 深の影響が排除でき, しかも赤土堆積状況をよく反映し らる指標を新たに導いた。 またそれを実際に沖縄のリー フ海域データに適用することにより，その有効性を確認 した.

ただし，式（6）の形からわかるように，この指標は 赤土やリーフの分光反射特性が解析対象領域内でほぼ一 定であることを前堤としている．実際にはこの仮定は成 立するとは限らないので，その点を考慮した改良を今後 行っていく必要がある.

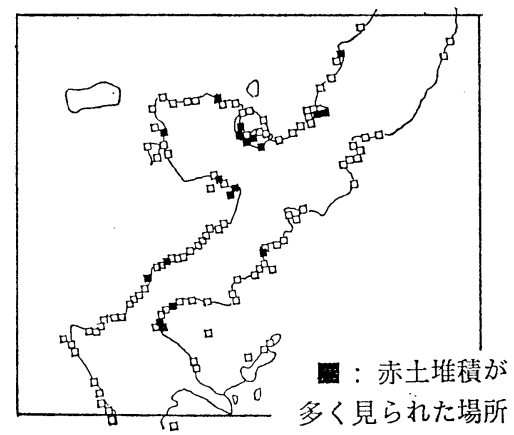

図一-8 現地サンプリングデータによる赤土堆積状況（大見 謝・池間，1990)

なお，沖縄赤土問題をより包括的に把握するには海域 データの解析だけでは不十分で陸域データの解析も連結 させた『海・陸統合型の解析』が必要となる。この点 は，従来の沿岸海洋污染解析に打いて抜け落ちている視 点で, その意味で沖縄赤土問題は格好の研究対象になっ ている、これ関する解析結果は別飞発表する予定であ る（灘岡・田村，1991）。

謝辞：本研究を行うにあたり, 沖縄県公害衛生研究 所の大見謝辰男氏，ならびにリモートセンシング技術セ ンターの田中総太郎氏には有益な御教示を頂いた。ここ に記して謝意を表します。

\section{参 考 文 献}

大見謝辰男・池間修宏 (1990)：沖縄県内各地の海域における 赤土污濁の現状, 沖縄県公衆衛生学会誌・別刷 21 号, pp. $1-15$.

翁長謙良 - 他 (1990)： 総合赤土砂対策検討調査報告書, 財団法 人日本土壤協会, $74 \mathrm{p}$.

黒田泰弘・他共訳 (1977)： 人工衛星写真りモートセンシング, 朝倉書店, $180 \mathrm{p}$.

沢本正樹・季立 覀・村越 潤 (1985)：駿河湾抽よび天竜川 の河口流出の解析, 第 32 回海岸工学講演会論文集, pp. 767-771.

杉森康宏 (1982)： 海洋のリモートセンシング，共立出版， 254 p.

灘岡和夫・田村英寿 (1991)：LANDSAT TM データに基づ いた沖縄赤土流出問題の解析の試み, 日本りモートセンシ ング学会誌，投稿予定. 